\title{
The Influence of Conventional Heating and Microwave Irradiation on the Resolution of (RS)-sec-Butylamine Catalyzed by Free or Immobilized Lipases
}

\author{
Cristiane Pilissão, ${ }^{a}$ Patrícia de Oliveira Carvalho ${ }^{b}$ and Maria da Graça Nascimento ${ }^{*, a}$ \\ ${ }^{a}$ Departamento de Química, Universidade Federal de Santa Catarina, \\ 88040-900 Florianópolis-SC, Brazil \\ ${ }^{b}$ Curso de Farmácia, Universidade São Francisco, Av. S. Francisco, 218, \\ 12916-900 Bragança Paulista-SP, Brazil
}

\begin{abstract}
As lipases CAL-B, LPS, LPS-C, LPS-D e a de A. níger, livres ou imobilizadas em filmes de amido de cará (Discorea alata L.), inhame (Colocasia esculenta (L.) Schott) ou de gelatina, foram utilizadas na acilação da $(R S)$-sec-butilamina com diferentes doadores acila em vários solventes orgânicos sob aquecimento convencional $(\mathrm{CH})$ ou irradiação por microondas (MW). Ao utilizar a lipase de A. niger livre, a conversão foi três vezes maior sob irradiação por $\mathrm{MW}$ em relação ao $\mathrm{CH}$ a $35^{\circ} \mathrm{C}$. Usando a lipase de $A$. niger livre, a $(R)$-amida foi obtida com $21 \%$ de conversão, resultando em valores de $e e_{\mathrm{p}}>99 \%$ e de $\mathrm{E}$ (enantiosseletividade) > 200, em 1 min de reação em MW. Ao utilizar a lipase de A. niger imobilizada em filmes de amido de cará e inhame, em 3 ou 5 min de reação em MW, a amida foi obtida com conversões moderadas, sendo de 8 a $25 \%$, porém com maior seletividade $\left(e e_{\mathrm{p}}>99 \%\right.$ e E > 200) em comparação à forma livre ( $45 \%$ de conversão, $e e_{\mathrm{p}} 81 \%$ e 18 para o valor de E).
\end{abstract}

The lipases CAL-B, PSL, PSL-C, PSL-D, and A. niger lipase, free or immobilized in starch (obtained from two types of yam, known in Brazil as "cará" (Discorea alata L.) and "inhame" (Colocasia esculenta (L.) Schott) or gelatin films, were used in the acylation of $(R S)$-sec-butylamine with different acyl donors in various organic solvents applying conventional heating $(\mathrm{CH})$ or microwave (MW) irradiation. In the case of free A. niger lipase, the conversion degrees were three times higher using MW irradiation when compared to conventional heating at $35{ }^{\circ} \mathrm{C}$. Using free A. niger lipase, the $(R)$-amide was obtained with a conversion degree of $21 \%$, resulting in $e e_{\mathrm{p}}>99 \%$ and E-value (enantioselectivity value) $>200$, in $1 \mathrm{~min}$ of reaction under MW irradiation. When the $A$. niger lipase was immobilized in yam starch films, the $(R)$-amide was obtained in moderate conversions of $8-25 \%$ after 3 or 5 min of reaction under MW irradiation, but with higher selectivity $\left(e e_{\mathrm{p}}>99 \%\right.$ and $\left.\mathrm{E}>200\right)$ in comparison with the free form (conversion degree of $45 \%, e e_{\mathrm{p}} 81 \%$ and E value of 18).

Keywords: enzymatic resolution, lipase, immobilization, microwave irradiation

\section{Introduction}

Biocatalysts are an attractive alternative to conventional methods for effecting asymmetric organic transformations, offering unique characteristics when compared to homogeneous or heterogeneous chemical catalysts. Biocatalytic reactions are also generally safer and the reaction conditions are mild. ${ }^{1-3}$

Lipases (triacylglycerol acyl hydrolases, EC 3.1.1.3) are considered the most ubiquitous and valuable enzymes for asymmetric synthesis. Lipase applications include

\footnotetext{
*e-mail: maria.nascimento@ufsc.br
}

the kinetic resolution of racemic alcohols, acids, esters or amines as well as desymmetrization of prochiral compounds and the efficient synthesis of chiral building blocks, drugs and fragrances. ${ }^{4-6}$

The synthesis of optically pure amides is an area of growing interest in synthetic chemistry. Amines and their derived amides are important compounds in organic synthesis because of the presence of these functional groups in many pharmacologically active compounds such as $(S)$-methyldopa and $(S)$-penicillin. ${ }^{6-10}$

The classic amide synthesis method is the reaction of carboxylic acids with amines at high temperature. Due to the low activity of carboxylic acids, various methods for 
their activation have been reported in the literature. The most common is the conversion of a carboxylic acid to a more reactive functional group, such as an acyl chloride, mixed anhydride, acyl azide or an active ester. ${ }^{10,11}$

In the last decade, microwave (MW) irradiation has been used to simplify and improve the reaction conditions for many classic organic reactions. Reactions performed under MW irradiation proceed faster, are cleaner, present much better yields and are more reproducible than those performed under conventional conditions. ${ }^{12-17}$ Besides, in some enzymatic reactions the selectivity, such as stereoselectivity or regioselectivity, are clearly influenced. ${ }^{17-19}$

Yu et al..$^{18}$ observed that MW irradiation increased both the activity and enantioselectivity of novozym 435 , and also the thermal stability and reusability in the resolution of $(R S)$-2-octanol with vinyl acetate as the acyl donor. A conversion of $50 \%$ was achieved in a $3 \mathrm{~h}$ reaction under MW irradiation while around $12 \mathrm{~h}$ was required to obtain the same conversion under conventional heating. Using the optimum conditions and applying MW irradiation (S)-2-octanol was obtained at 50.5\% conversion with 99\% of enantiomeric excess in $2 \mathrm{~h}$ reaction.

Recently, the kinetic resolution of ( \pm )-mandelonitrile was studied using lipase from Candida antarctica under conventional condition and MW irradiation in toluene. In both conditions, the $(S)$-mandelonitrile acetate was obtained with high selectivity (ee of $92-98 \%$ ). ${ }^{19}$

However, most enzymes are deactivated by the fast increase in temperature under MW irradiation. ${ }^{18}$ This problem may be solved by the use of immobilized enzymes which, in general, exhibit higher thermal stability than the free form. ${ }^{20,21}$

Enzyme immobilization in different supports is an important technique used to increase the productivity of synthetic reactions in organic media. In general, immobilized enzymes are more stable in relation to changes in $\mathrm{pH}$ and temperature compared to free forms. Moreover, they remain stable for months and the catalyst can be used repeatedly. Thus, they are easy to handle and can be recovered from solution, which makes the process practical and economically viable. Enzymes can be immobilized in organic and/or inorganic material for their use in synthesis. These materials include biopolymers, organogels, glass, silica and nanoparticles. ${ }^{21-27}$

Yadav and Lathi ${ }^{28}$ reported that the initial activity for the transesterification of methyl acetoacetate with various alcohols in the presence of immobilized lipases, such as novozym 435, lipozyme RM IM and lipozyme TL IM, was around 2.2-4.6 times greater when using MW irradiation than in $\mathrm{CH}$ reactions. The reaction followed the ping-pong bi-bi mechanism.

In this study the influence of both temperaturecontrollable microwave (MW) assisted irradiation and conventional heating $(\mathrm{CH})$ was evaluated in the enzymatic resolution of $(R S)$-sec-butylamine using different acyl donors (ethyl acetate, vinyl acetate and isopropyl acetate). The reaction was catalyzed by four commercial lipases, one from Pseudomonas cepacia (PSL) free or immobilized in films produced from yam starch (obtained from "cará" or "inhame", referred herein to yam I and yam II, respectively) or gelatin, and three commercial samples: two of immobilized P. cepacia lipase (PSL-C and PSL-D) and one of immobilized Candida antarctica lipase (novozym 435 - CAL-B). The behavior of the native $A$. niger lipase, free or immobilized in yam starch or gelatin films, was also evaluated (Scheme 1).

\section{Experimental}

\section{Materials and methods}

The following lipases produced by Pseudomonas cepacia were received from Amano Pharmaceutical Co. (Nagoya, Japan): PSL (30,000 U g-1 $)$, (PSL-D) (immobilized on diatomaceous earth, $500 \mathrm{U} \mathrm{g}^{-1}$ ), and PSL-C (immobilized on diatomite and chemically-modified ceramics, $600 \mathrm{U} \mathrm{g}^{-1}$ ). Lipase produced by Candida antarctica

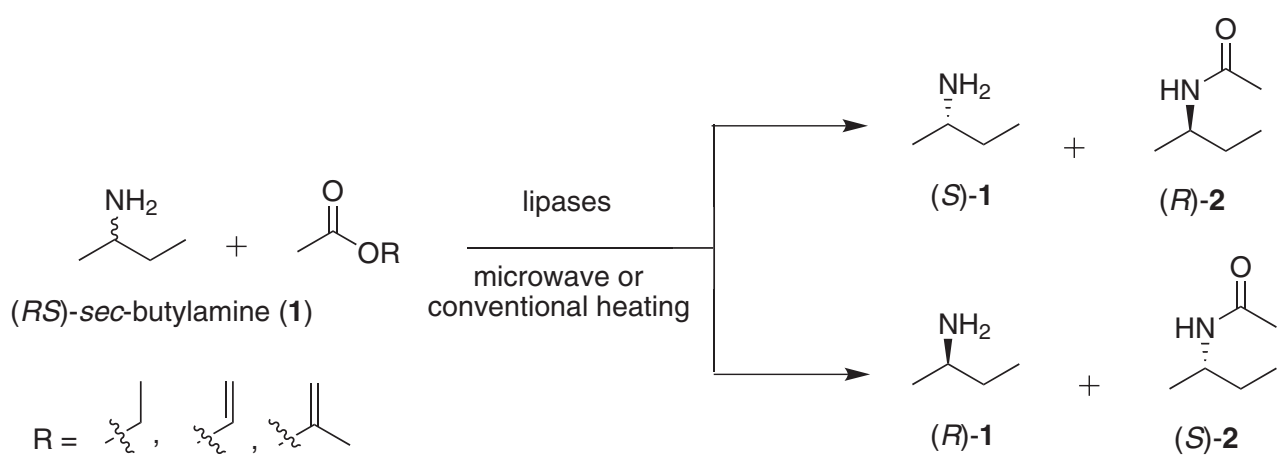

Scheme 1. Acylation of $(R S)$-sec-butylamine (1) with different acyl donors mediated by lipases using MW irradiation or conventional heating $(\mathrm{CH})$. 
(CAL-B, novozym 435, 10,000 PLU g-1 immobilized on a polyacrylate resin) was received from Novozymes Latin America Ltda (Brazil) and lipase produced by Aspergillus niger AC-54 (lipase activity $2.86 \mu \mathrm{mol} \mathrm{min}^{-1} \mathrm{mg}^{-1}$ for the hydrolysis of olive oil at $\mathrm{pH} 6.0$ and $40^{\circ} \mathrm{C}$ ) was isolated and purified as previously described. ${ }^{29,30}(R S)$-sec-butylamine $(99 \%)$ and $(R)$-sec-butylamine $(99 \%)$ were purchased from Sigma-Aldrich. $n$-Hexane, $n$-heptane, cyclohexane, toluene, acetonitrile, ethyl acetate, vinyl acetate and isopropenyl acetate were obtained from Vetec (Brazil), Fluka and Sigma-Aldrich at the highest available purity (> 99\%). The starch was obtained from vegetable roots of yam I or yam II, and was extracted as previously described for ginger starch. ${ }^{27}$ The pharmaceutical-grade gelatin was obtained from Sigma-Aldrich (300 Bloom).

\section{Immobilization of lipases in starch and gelatin films}

The yam starch (two types) and gelatin films were prepared by dissolving $1.0 \mathrm{~g}$ of starch (from yams I and II separately) or gelatin in $25 \mathrm{~mL}$ of distilled water ( $\mathrm{pH} 5.6$ ) in a $50 \mathrm{~mL}$ beaker. The mixture was kept under mild heating $\left(\right.$ ca. $60{ }^{\circ} \mathrm{C}$ ) and constant magnetic stirring until complete dissolution of the polymers occurred. Glycerol $(0.3 \mathrm{~mL})$ and the lipases $(50 \mathrm{mg}$ ) were then added to the solution and the mixture was stirred for another $20 \mathrm{~min}$. The solution was transferred to a Petri dish and heated in a sand bath at $40{ }^{\circ} \mathrm{C}$ for water evaporation. The films with the immobilized enzymes were cut into small and regular pieces and kept in organic solvent for later use.

The water content present in the films obtained from the yam I and yam II starch or gelatin was determined by Karl-Fisher titration. The films contained between $10-14 \%$ of water, an amount sufficient to maintain the three-dimensional structure of the enzyme and consequently its activity. ${ }^{31,32}$

The activities of the free or immobilized lipases were determined by the hydrolysis of olive oil which is based on the method proposed by Thomson et al. ${ }^{33}$ One unit of lipolytic activity was defined as the amount of enzyme that releases one micromole of fatty acid per min under test conditions ( $\mathrm{pH} 6.0,40{ }^{\circ} \mathrm{C}$ in $1 \mathrm{~h}$ reaction) (results presented in Table 1).

\section{Preparation of $(R)$-sec-butylacetamide}

Volumes of $2.50 \mathrm{~mL}$ ( $25 \mathrm{mmol})$ of $(R)$-sec-butylamine and $4 \mathrm{~mL}(50 \mathrm{mmol})$ of pyridine in $50 \mathrm{~mL}$ of chloroform were transferred to a $250 \mathrm{~mL}$ beaker. To this solution 5 $\mathrm{mL}$ of acetic anhydride $(50 \mathrm{mmol})$ were added drop by drop. The reaction medium was kept under mechanical stirring and cooled in an ice bath for $0.5 \mathrm{~h}$. The amide was purified by extraction with an aqueous solution of $5 \%$ hydrochloric acid $(3 \times 10 \mathrm{~mL})$ and $5 \%$ of sodium bicarbonate $(3 \times 10 \mathrm{~mL})$ using ethyl ether $(3 \times 10 \mathrm{~mL})$. The organic phase was dried over anhydrous magnesium sulfate $\left(\mathrm{MgSO}_{4}\right)$ and the solvent was then evaporated. Pure $(R)$-sec-butylacetamide was obtained with a specific optical rotation $[\alpha]=-8.87\left(0.09 \mathrm{~g} \mathrm{~mL}^{-1}, \mathrm{CHCl}_{3}\right)$. This value presented the same sign reported for $(R)$-sec-butylamine; $[\alpha]=-7.50(\mathrm{c}=$ neat $) .{ }^{34}{ }^{1} \mathrm{H} \mathrm{NMR}\left(400 \mathrm{MHz}, \mathrm{CDCl}_{3}\right) \delta 0.91$ $(3 \mathrm{H}, \mathrm{t}, J 7.2 \mathrm{~Hz}, \mathrm{H} 5), 1.12(2 \mathrm{H}, \mathrm{d}, J 6.8 \mathrm{~Hz}, \mathrm{H} 4), 1.46(2 \mathrm{H}$, q, H3), 1.98 (3H, s, H6), 3.89 (1H, sex, H2), $5.76(1 \mathrm{H}, \mathrm{s}$, $\mathrm{H} 1)$; IR (KBr) $v_{\max } / \mathrm{cm}^{-1}: 3287(\mathrm{NH}), 2973-2932(\mathrm{C}-\mathrm{H}$ aliphatic), $1647(\mathrm{C}=\mathrm{O}), 1558(\mathrm{NH}){ }^{35}$

General procedure for lipase-catalyzed resolution of $(R S)$-sec-butylamine (1)

In these reactions, $0.2 \mathrm{~mL}(2 \mathrm{mmol})$ of $(R S)-\mathrm{sec}$ butylamine (1) and different acyl donors (2-8 mmol), such as ethyl acetate, vinyl acetate and iso-propenyl acetate, were used. The lipases $(50 \mathrm{mg}$ ), free or immobilized in the starch or gelatin films and different organic solvents $(7$ or $10 \mathrm{~mL})$ ( $n$-hexane, $n$-heptane, ciclohexane, toluene, chloroform, dichloromethane and tert-butanol) were then added. The reaction mixture was shaken in a rotary shaker $(200 \mathrm{rpm})$ and heated to $20-50^{\circ} \mathrm{C}$ in a water bath (Tecnal TE-093) or in a microwave oven (MW irradiation). The reactions carried out under MW irradiation were performed in a $\mathrm{CEM}^{\circledR}$ Discover benchmate microwave reactor with temperature monitored by a built-in infrared sensor. A mixture of $0.2 \mathrm{~mL}$ $(2 \mathrm{mmol})$ of $(R S)$-sec-butylamine and $0.2 \mathrm{~mL}(2 \mathrm{mmol})$ of ethyl acetate, $7 \mathrm{~mL}$ of the different organic solvents and A. niger lipase $(50 \mathrm{mg})$, free or immobilized, was placed in a $10 \mathrm{~mL}$ glass $\mathrm{MW}$ tube with a magnetic stirrer. The vial was then sealed with a septum and the reaction mixture placed into the reactor, closed and subjected to a maximum power of $50 \mathrm{~W}$ at $50 \mathrm{PSI}$ pressure and $50{ }^{\circ} \mathrm{C}$. The total reaction time was the sum of five successive irradiation pulses of $1 \mathrm{~min}$, not considering the ramp time ( $1 \mathrm{~min}$ ) for each applied pulse.

The reaction progress and enantiomeric excesses values were determined with a gas chromatograph (GC, Shimadzu14B) equipped with a chiral column (Rt- $\beta$ DEXsm $30 \mathrm{~m} \times 0.32 \mathrm{~mm} \times 0.25 \mathrm{~mm}$, Restek). $\mathrm{H}_{2}$ was used as the carrier gas, the detector and injector were set at $230^{\circ} \mathrm{C}$, and the column was ramped from 50 to $200{ }^{\circ} \mathrm{C}$ at $3{ }^{\circ} \mathrm{C} \mathrm{min}^{-1}$. The retention time of $R$-amide 2 was $11.62 \mathrm{~min}$, and this was compared with an enantiopure standard compound using chiral gas chromatography. The retention time of $(S)$-amide 2 was $11.30 \mathrm{~min}$. The enantioselectivity values 
(E-values) were calculated from the enantiomeric excess of the product $\left(e e_{\mathrm{p}}\right)$ and the conversion degree (c) according to the method described by Chen et al. ${ }^{36}$ and Sih and $\mathrm{Wu} .{ }^{37}$

The specific conditions of each study will be described in the results and discussion for each experiment. Control experiments were conducted without lipases under similar reaction conditions, and no product was obtained.

\section{Results and Discussion}

\section{Screening of lipases}

In a first approach, five lipases from different sources were screened in the acylation of $(R S)$-sec-butylamine (1) with ethyl acetate in $n$-hexane at $35^{\circ} \mathrm{C}$, under $\mathrm{CH}$. Lipases produced by $C$. antarctica (CAL-B), P. cepacia (PSL, PSL-C and PSL-D) and the native A. niger free or immobilized in yam starch or gelatin films were selected for this study. The results are presented in Table 1.

The products were analyzed by chiral gas chromatography and in most studies the $(R)$-amide 2 was the main product. These data followed the empirical rule proposed by Kazluaskas and Weissfloch ${ }^{38}$ and are in agreement with data reported in the literature which shows that CAL-B and other lipases have a highly pronounced catalytic preference for the $R$-enantiomer.

In general, the conversion degrees and E-values were dependent on the lipase source and activity. When the commercial lipases PSL-C and PSL-D, free or immobilized in starch or gelatin films, were employed low values (0-5\%) for the conversion into the corresponding amide and low E-values $(<2.0)$ were obtained in $6 \mathrm{~h}$ of reaction (Table 1, entries 1-6).
When CAL-B was used as the biocatalyst the degree of conversion into $(R)$ - amide 2 was $54 \%$ with an $e e_{\mathrm{p}}$ value of $84 \%$, resulting in an E-value of $30 \mathrm{in} 0.5 \mathrm{~h}$ of reaction. The selectivity of CAL-B for this reaction (expressed by the E-value) can be considered as moderate (Table 1, entry 7).

When the native A. niger lipase was employed, free or immobilized, the conversion degrees were in the range of $15-41 \%$, resulting in $e e_{\mathrm{p}}$ and E-values of 81-89\% and 10-32 in $1 \mathrm{~h}$ of reaction, respectively (Table 1, entries 8-11). In $2 \mathrm{~h}$ of reaction the $(R)$-amide 2 was obtained in conversion degrees of $24-46 \%$ with $e e_{\mathrm{p}}$ and E-values of $82-84 \%$ and 13-21, respectively (data not presented in Table 1). As previously mentioned, in general, using longer reaction times, the amide 2 was formed in higher conversion degrees but with lower $e e_{\mathrm{p}}$ and E-values.

As discussed above, these data show the influence of using free or immobilized lipases in the resolution of (RS)-sec-butylamine. Furthermore, using the free A. niger lipase improved the results for the conversion degrees and selectivity compared to the use of immobilized lipase in $1 \mathrm{~h}$ of reaction. Using CAL-B, the conversion degree was higher (54\%) than that obtained using the A. niger lipase $(15-41 \%)$ in a shorter reaction time, however the E-values were similar (Table 1, entries 7 and 8).

These preliminary results showed that the A. niger lipase presented good potential for use in the resolution of $(R S)$-1. It is also important to consider the exploration of non-commercial lipases obtained from the great diversity of potential source species available in Brazil, especially in asymmetric synthesis. This lipase has previously been used for the resolution of ibuprofen ${ }^{29}$ and $(R S)$-phenylethylamine. ${ }^{39}$ The potential of this biocatalyst for industrial use has also been described recently. ${ }^{5}$ Thus,

Table 1. Acylation of (RS)-sec-butylamine (1) with ethyl acetate using different free and immobilized lipases under conventional heating

\begin{tabular}{|c|c|c|c|c|c|c|}
\hline entry & lipase & lipase activity & time $/ \mathrm{h}$ & $\mathrm{c} / \%$ & $e e_{\mathrm{p}} / \%(R)-\mathbf{2}$ & E-value ${ }^{a}$ \\
\hline 1 & LPS & $10.72^{\mathrm{b}}$ & 6 & 5 & 25 & 1.7 \\
\hline 2 & PSL/yam II & $33.4^{\mathrm{b}}$ & 6 & - & - & - \\
\hline 3 & PSL/yam I & $17.6^{\mathrm{b}}$ & 6 & 5 & 14 & 1.3 \\
\hline 4 & PSL/gelatin & $18.40^{\mathrm{b}}$ & 6 & - & - & - \\
\hline 5 & PSL-D & $1.69^{\mathrm{c}}$ & 6 & - & - & - \\
\hline 6 & PSL-C & $2.35^{\mathrm{c}}$ & 6 & - & - & - \\
\hline 7 & CAL-B & $3.04^{c}$ & 0.5 & 54 & 84 & 30 \\
\hline 8 & A. niger & $2.86^{\mathrm{b}}$ & 1 & 41 & 89 & 32 \\
\hline 9 & A. niger/yam II & $10.8^{\mathrm{b}}$ & 1 & 15 & 81 & 10 \\
\hline 10 & A. niger/yam I & $0.80^{\mathrm{b}}$ & 1 & 37 & 85 & 20 \\
\hline 11 & A. niger/gelatin & $4.20^{\mathrm{b}}$ & 1 & 30 & 89 & 24 \\
\hline
\end{tabular}

Reaction conditions: $(R S)-\mathbf{1}(0.20 \mathrm{~mL}, 2 \mathrm{mmol})$, ethyl acetate $(0.20 \mathrm{~mL}, 2 \mathrm{mmol}), n$-hexane $(10 \mathrm{~mL})$, enzyme $(50 \mathrm{mg}), 35^{\circ} \mathrm{C}$; aenantiomeric ratio; ${ }^{\mathrm{b}} \mathrm{U} \mathrm{g}^{-1}$;

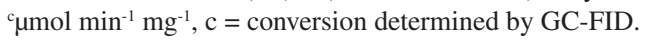


the A. niger lipase was selected for use in the studies that followed, which included the effect of acyl donor, temperature, organic solvents and the use of immobilized A. niger lipase under $\mathrm{CH}$ and $\mathrm{MW}$ irradiation.

\section{Effect of type and amount of acyl donor}

In the next study, the type and relative amount of acyl donor were evaluated for the resolution of $(R S)$ - $\mathbf{1}$ using free A. niger lipase as the biocatalyst. Firstly, for this study three acyl donors (ethyl acetate, vinyl acetate and iso-propenyl acetate) were screened. The results for the conversion degrees and $e e_{\mathrm{p}}$ values are presented in Figure 1.

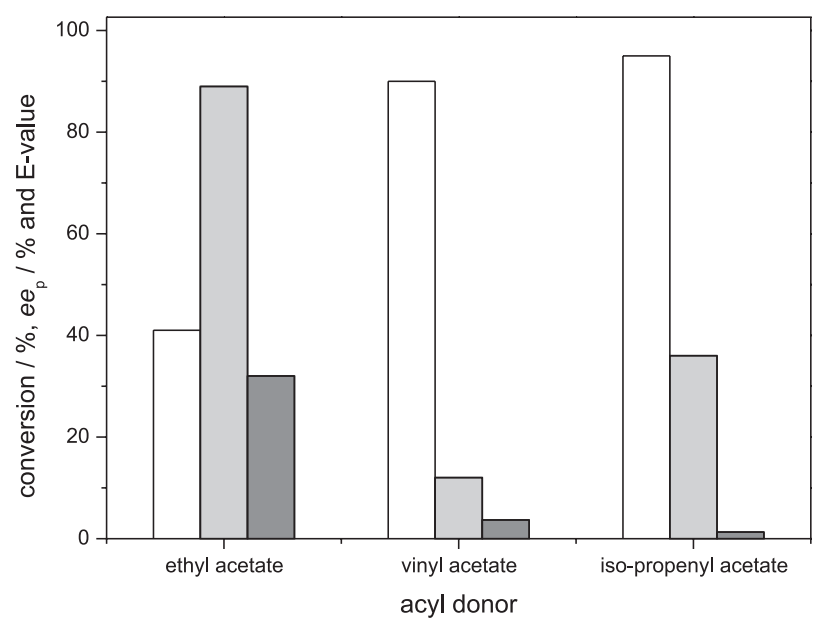

Figure 1. Influence of acyl donor type on the resolution of (RS)-secbutylamine (1) catalyzed by free A. niger lipase. Reaction conditions: $(R S)-1(0.20 \mathrm{~mL}, 2 \mathrm{mmol})$, ethyl acetate $(0.20 \mathrm{~mL}, 2 \mathrm{mmol}), n$-hexane $(10 \mathrm{~mL})$, enzyme $(50 \mathrm{mg}), 1 \mathrm{~h}, 35^{\circ} \mathrm{C},(\square) \mathrm{c}(\%),(\square) e e_{\mathrm{p}}(\%),(\square)$ E-value.

The results showed that when vinyl acetate or isopropenyl acetate were used the amide was formed with conversions of 90 and $95 \%$, resulting in $e e_{\mathrm{p}}$ values of 12 and $36 \%$ and E-values of 3.7 and 1.3, respectively, in $1 \mathrm{~h}$ reaction. As observed, vinyl and iso-propenyl acetate were good acyl donors and formed the racemic amide with high conversion degrees. However, the E-values are low and considered unacceptable for practical purposes, especially in enzymatic resolution. ${ }^{3}$

These data are in agreement with those presented by Bachu et al. ${ }^{12}$ These authors reported that the use of vinyl acetate and iso-propenyl acetate is not always advantageous in biocatalysis because they can form undesirable side products, such as acetaldehyde or acetone which are toxic to the enzyme and can denature the biocatalyst.

However, when ethyl acetate was used, the $(R)$-amide 2 was formed with a conversion degree of $41 \%$, resulting in $e e_{\mathrm{p}}$ and E-values of $89 \%$ and 32 , respectively. Thus, ethyl acetate was selected to evaluate the molar ratio between the $(R S)$-sec-butylamine (1) and the acyl donor, which ranged from 1:1 to 1:5. The results are presented in Figure 2.

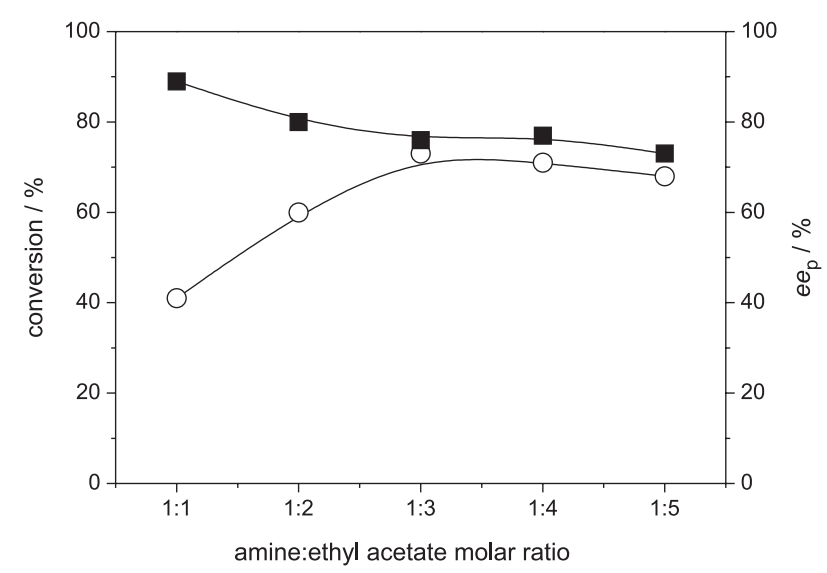

Figure 2. Influence of molar ratio on the acylation of $(R S)$-sec-butylamine (1) with ethyl acetate using free lipase from A. niger. Reaction conditions: $(R S)-1(0.20 \mathrm{~mL}, 2 \mathrm{mmol})$, ethyl acetate $(2-8 \mathrm{mmol}), n$-hexane $(10 \mathrm{~mL})$, enzyme $(50 \mathrm{mg}), 1 \mathrm{~h}, 35^{\circ} \mathrm{C},(\bigcirc)$ conversion $(\%)$ and $(\mathbf{\square}) e e_{\mathrm{p}}(\%)$.

The data show that the degrees of conversion to the $(R)$-amide $\mathbf{2}$ increased from 41 to $73 \%$ as the molar ratio increased from 1:1 to 1:3. However, a decrease in the $e e_{\mathrm{p}}$ values from 89 to $76 \%$ was observed. Using a molar ratio of 1:4 and 1:5, the conversion degrees (71 and 68\%) and $e e_{\mathrm{p}}$ values (77 and $73 \%$ ) remained practically constant and were similar to those obtained when a molar ratio of $1: 3$ was used.

The best result in relation to selectivity was achieved when a molar ratio of amine:ethyl acetate 1:1 was used and this value was therefore selected for use in the subsequent studies to investigate the effects of temperature and organic solvents under $\mathrm{CH}$ and MW irradiation.

\section{Effect of temperature}

The reaction temperature is important in catalysis. This parameter can influence the activity, selectivity and the stability of the biocatalyst. ${ }^{18,40}$

In this study four different temperatures, ranging from 35 to $50{ }^{\circ} \mathrm{C}$, were evaluated in the acylation of $(R S)-1$ with ethyl acetate in $n$-hexane applying conventional heating $(\mathrm{CH})$ or MW irradiation for $3 \mathrm{~min}$. This reaction time was selected considering that for longer times the conversion degrees were higher than $50 \%$, and thus unsuitable for enzymatic resolution (results not presented). Figure 3 shows the formation of $(R)$-amide $\mathbf{2}$ at various temperatures.

When $\mathrm{CH}$ was used the $(R)$-amide $\mathbf{2}$ was obtained with conversion degrees of $13-51 \%$, resulting in $e e_{\mathrm{p}}$ and E-values of $81-90 \%$ and $21-23$, respectively, as the temperature increased from 35 to $45^{\circ} \mathrm{C}$. A decrease in the conversion degree and the $e e_{\mathrm{p}}$ and E-values was observed 


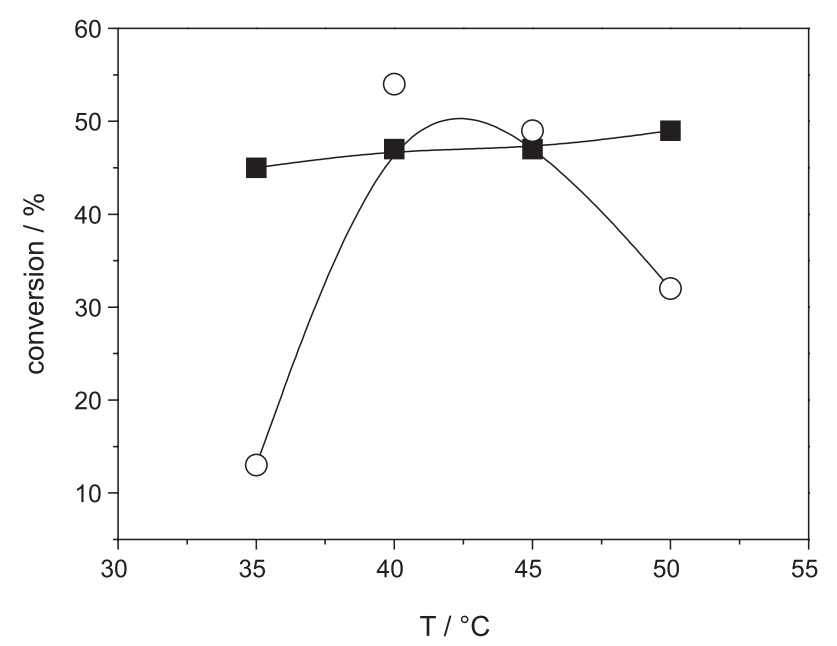

Figure 3. Influence of temperature $\left({ }^{\circ} \mathrm{C}\right)$ on the conversion degrees $(\%)$ in the acylation of $(R S)$-sec-butylamine (1) with ethyl acetate using free A. niger lipase. Reaction conditions: $(R S)-\mathbf{1}(0.20 \mathrm{~mL}, 2 \mathrm{mmol})$, ethyl acetate $(0.20 \mathrm{~mL}, 2 \mathrm{mmol}), n$-hexane $(10 \mathrm{~mL})$, enzyme $(50 \mathrm{mg}), 3 \mathrm{~min}$; (ם) microwave irradiation $(O)$ conventional heating.

at $50{ }^{\circ} \mathrm{C}$, these values being $32 \%, 81 \%$ and 13 , respectively. The stability of this lipase was probably lower due to denaturation of this biocatalyst at higher temperatures. As previously described, the A. niger lipase presented good thermostability in the range of 35 to $45^{\circ} \mathrm{C} .{ }^{30}$

Interesting results were obtained with the use of MW irradiation. The conversion degrees remained almost constant in the temperature range of 35 to $50^{\circ} \mathrm{C}$, and the $(R)$-amide 2 was formed with conversion degrees of $45-49 \%$, resulting in $e e_{\mathrm{p}}$ and E-values of $80-81 \%$ and $18-20$, respectively.

Using MW irradiation, the conversion degrees were higher than those obtained with the use of $\mathrm{CH}$ at temperatures of 35 and $50{ }^{\circ} \mathrm{C}$. At $35{ }^{\circ} \mathrm{C}$ the $(R)$-amide 2 was formed with conversion degrees of $45 \%$ under MW irradiation and $13 \%$ under $\mathrm{CH}$, respectively. This result showed the important influence of MW irradiation, especially on the degree of conversion into the product. However, no significant changes in the $e e_{\mathrm{p}}$ and E-values were observed.

In order to improve the selectivity under MW irradiation, the resolution of $(R S)$-1 was performed for $1 \mathrm{~min}$. When the reaction was conducted under MW irradiation for $1 \mathrm{~min}$ at $35^{\circ} \mathrm{C}$ the $(R)$-amide 2 was obtained with a conversion degree of $21 \%$, resulting in $e e_{\mathrm{p}}>99 \%$ and $\mathrm{E}>200$. However, when the reaction was carried out for $1 \mathrm{~min}$ using $\mathrm{CH}$, no product was detected (data not presented in Figure 3). These results also showed the positive influence of MW irradiation on both conversion and selectivity. Similar results were obtained by Huang et al. ${ }^{20}$ in the enzymatic esterification of $n$-alcohol homologs and caprylic acid, and the results were explained considering thermal and non-thermal effects.
Yadav and Borkar ${ }^{41}$ studied the effect of temperature on the synthesis of citronellyl acetate catalyzed by CAL-B in toluene, at $30-60{ }^{\circ} \mathrm{C}$, using $\mathrm{CH}$ and $\mathrm{MW}$ irradiation. The results showed that the conversion degrees and reaction rates were higher when MW irradiation was used compared to $\mathrm{CH}$. With the use of $\mathrm{CH}$, an increase in the initial rate from 0.01 to $0.025 \mathrm{~mol} \mathrm{~L}^{-1} \mathrm{~min}^{-1}$ was observed, whereas under MW irradiation the increase was from 0.015 to $0.045 \mathrm{~mol} \mathrm{~L}^{-1} \mathrm{~min}^{-1}$. In this study the temperature of $50{ }^{\circ} \mathrm{C}$ was selected as optimal.

Thus, considering the above results, the temperature of $35{ }^{\circ} \mathrm{C}$ was selected to evaluate the effect of organic solvent as well as the immobilization of $A$. niger lipase in different supports.

\section{Effect of organic solvent}

The organic solvent, in general, influences the selectivity of an enzyme because it can alter the native conformation and thus the catalytic activity of the biocatalyst. However, although there is still no consensus on the main parameters which influence the enzymatic reaction, the most frequently considered are the $\log \mathrm{P}$ (logarithm of the partition coefficient of the solvent for a standard octanol/water twophase system) and the dielectric constant. The hydrophobic solvents with $\log \mathrm{P} \geq 4$ are considered the most suitable biocatalysts for reactions. Solvents with $\log \mathrm{P}$ between 2 and 4 are considered moderate and the polar solvents with $\log \mathrm{P}<2$ are often inefficient for reactions catalyzed by enzymes. Although the $\log \mathrm{P}$ values do not correlate directly with the efficiency of enzymatic synthesis, this is a valuable information in terms of the initial selection of solvents. ${ }^{42,43}$

The solvent of choice also is important for use in microwave irradiation. With the use of polar solvents, the energy is transferred from the solvent to the reaction mixture and thus the results may be similar using MW irradiation or $\mathrm{CH}$. However, when more apolar solvents are used, the energy is transferred from the reagents to the solvent and the results can be improved by using MW irradiation rather than $\mathrm{CH} .{ }^{13,18,44}$

Thus, to evaluate this effect, solvents with different polarities, that is, $n$-heptane ( $\log \mathrm{P} 4.00), n$-hexane ( $\log$ P 3.90), cyclohexane ( $\log$ P 3.20), toluene ( $\log$ P 2.50 ), chloroform ( $\log \mathrm{P} 2.00)$, tert-butanol (log P 1.45) and dichloromethane (log $\mathrm{P} 1.18)$, were screened in the resolution of $(R S)$-1 with ethyl acetate, under $\mathrm{CH}$ or MW irradiation, catalyzed by the free $A$. niger lipase. The results are presented in Table 2.

The time of $1 \mathrm{~h}$ was selected for the studies applying $\mathrm{CH}$ based on the results obtained using free $A$. niger lipase in $n$-hexane (see Table 1, entry 8). In the case of MW irradiation the time selected was $1 \mathrm{~min}$, considering that 
Table 2. Effect of organic solvent on the acylation of the (RS)-sec-butylamine (1) with ethyl acetate under conventional heating or MW irradiation

\begin{tabular}{|c|c|c|c|c|c|c|c|c|}
\hline \multirow{2}{*}{ entry } & \multicolumn{4}{|c|}{ Conventional heating } & \multicolumn{4}{|c|}{ MW irradiation } \\
\hline & solvent & $\log \mathrm{P}^{\mathrm{a}}$ & $\mathrm{c} / \%$ & $e e_{\mathrm{p}} / \%$ & E-value & $\mathrm{c} / \%$ & $e e_{\mathrm{p}} / \%$ & E-value \\
\hline 1 & $n$-heptane & 4.00 & 45 & 78 & 15 & 27 & 74 & 8.7 \\
\hline 2 & $n$-hexane & 3.90 & 41 & 89 & 32 & 21 & $>99$ & $>200$ \\
\hline 3 & cyclohexane & 3.20 & 52 & 86 & 45 & 18 & 80 & 10 \\
\hline 4 & toluene & 2.50 & 63 & 84 & 19 & 10 & 83 & 9 \\
\hline 5 & $\mathrm{CHCl}_{3}$ & 2.00 & 82 & 70 & 3.2 & 84 & 81 & 3.7 \\
\hline 6 & $t$-BuOH & 1.45 & 88 & 44 & 1.9 & 90 & 70 & 2 \\
\hline 7 & $\mathrm{CH}_{2} \mathrm{Cl}_{2}$ & 1.18 & 84 & 62 & 2.6 & 93 & 79 & 1.9 \\
\hline
\end{tabular}

Reaction conditions: (RS)-sec-butylamine (1) $(0.2 \mathrm{~mL}, 2 \mathrm{mmol})$, ethyl acetate $(0.2 \mathrm{~mL}, 2 \mathrm{mmol})$, solvent $(10 \mathrm{~mL}$ or $7 \mathrm{~mL}), A . n$ iger lipase $(50 \mathrm{mg}), 35^{\circ} \mathrm{C}$, $1 \mathrm{~h}$ of conventional heating or $1 \mathrm{~min}$ of MW irradiation. ${ }^{\mathrm{a} F r o m}$ reference 42.

for this reaction time good conversion degrees and $e e_{\mathrm{p}}$ and E-values were obtained (see data related to the temperature effects).

Applying $\mathrm{CH}$ and using apolar solvents ( $n$-hexane, $n$-heptane and cyclohexane) the $(R)$-amide 2 was obtained in moderate to good conversion degrees of 41,45 and $52 \%$, resulting in $e e_{\mathrm{p}}$ and $\mathrm{E}$ values of 89,78 and $86 \%$ and 32,15 and 45, respectively, in $1 \mathrm{~h}$ of reaction (Table 2 , entries 1-3). When toluene was used as the organic solvent the amide 2 was obtained with a conversion degree of $63 \%$, resulting in $e e_{\mathrm{p}}$ and $\mathrm{E}$-values of $84 \%$ and 19 , respectively which are not appropriate for enzymatic resolution (Table 2, entry 4).

When more polar solvents $\left(t\right.$ - $\mathrm{BuOH}, \mathrm{CH}_{2} \mathrm{Cl}_{2}$ and $\left.\mathrm{CHCl}_{3}\right)$ were used, the amide was formed with higher conversion degrees of 88,84 and $82 \%$, resulting in $e e_{\mathrm{p}}$ and $\mathrm{E}$ - values of 44,62 and $70 \%$ and 1.9, 2.6 and 3.2, respectively (Table 2, entries 5-7). These values are considered inadequate for enzymatic resolution; however these solvents proved to be good enough for use in the preparation of the racemic amide.

Using MW irradiation, the conversion degrees were also dependent on the organic solvent. The reaction time was much lower and in some cases the $e e_{\mathrm{p}}$ values were higher than those obtained using $\mathrm{CH}$.

Using apolar solvents ( $n$-hexane, $n$-heptane and cyclohexane) the $(R)$-amide 2 was obtained in moderate conversion degrees of 21,27 and $18 \%$, resulting in $e e_{\mathrm{p}}$ and E- values of $>99,74$ and $80 \%$ and $>200,8.7$ and 10, respectively, in $1 \mathrm{~min}$ of reaction (Table 2, entries 1-3). When toluene was used as the organic solvent, the amide was obtained with a conversion degree of $10 \%$, resulting in $e e_{\mathrm{p}}$ and E-values of $83 \%$ and 9 , which are considered inadequate for enzymatic resolution (Table 2, entry 4).

When more polar solvents $\left(t-\mathrm{BuOH}, \mathrm{CH}_{2} \mathrm{Cl}_{2}\right.$ and $\mathrm{CHCl}_{3}$ ) were used the amide was formed with higher conversion degrees of 90,93 and $84 \%$, resulting in $e e_{\mathrm{p}}$ and E-values of 70,79 and $81 \%$ and 2, 1.9 and 3.7, respectively (Table 2, entries 5-7). These values were similar to those obtained with $\mathrm{CH}$ and, as previously discussed, are not appropriate for enzymatic resolution.

The best result was achieved using $n$-hexane and applying MW irradiation for $1 \mathrm{~min}$, where the $(R)$-amide 2 was formed with a conversion degree of $21 \%$, resulting in $e e_{\mathrm{p}}$ and E-values $>99 \%$ and $>200$, respectively. On applying $\mathrm{CH}$, the conversion degree was $30 \%$, with $e e_{\mathrm{p}}$ and $\mathrm{E}$ values of $85 \%$ and 32, respectively, in $30 \mathrm{~min}$ of reaction (Table 2, entry 2). These results showed the positive effect of using MW irradiation on the enzymatic resolution of $(R S)$-1.

The data presented herein are consistent with previously reported results which showed that non-polar organic solvents do not absorb microwave energy efficiently, and thus do not warm the reaction medium and may act as "blockers", forming barriers to the heat produced by the interaction of microwave radiation and polar reagents. ${ }^{13,18}$

Yu et al..$^{18}$ described the transesterification of $(R S)$-2octanol with vinyl acetate catalyzed by CAL-B, using solvents with different polarities ( $n$-heptane, $n$-hexane, toluene, cyclohexane, acetone, acetonitrile, DMF and 1,4-dioxane) and applying $\mathrm{CH}$ and MW irradiation. The highest activity and enantioselectivity were obtained using $n$-heptane under MW irradiation. The enzyme activity was $203 \mu \mathrm{mol} \mathrm{min}^{-1} \mathrm{mg}^{-1}$ with an E-value of 352 . With the use of $\mathrm{CH}$ the enzyme activity and the E-value were $55 \mu \mathrm{mol} \mathrm{min}{ }^{-1} \mathrm{mg}^{-1}$ and 99 , respectively. Recently, the positive effect of ionic liquids associated with MW irradiation has also been described for this substrate. ${ }^{44}$

Based on these results, $n$-hexane was selected to evaluate the influence of using the lipase from A. niger immobilized in starch or gelatin films.

\section{Effect of using immobilized $A$. niger lipase}

In this study, the A. niger lipase was immobilized in yam starch (two types) or gelatin films and then used in 
Table 3. Effect of lipase immobilization on the acylation of $(R S)$-1 under conventional heating or MW irradiation

\begin{tabular}{|c|c|c|c|c|c|c|}
\hline \multirow[b]{2}{*}{ enzyme/support } & \multicolumn{3}{|c|}{ Conventional heating } & \multicolumn{3}{|c|}{ MW irradiation } \\
\hline & $\mathrm{c} / \%$ & $e e_{\mathrm{p}} / \%$ & E & $\mathrm{c} / \%$ & $e e_{\mathrm{p}} / \%$ & $\mathrm{E}$ \\
\hline Free A. niger & $13^{\mathrm{a}}$ & 90 & 21 & $45^{\mathrm{a}}$ & 81 & 18 \\
\hline A. niger/yam II starch & $-^{\mathrm{a}}$ & - & - & $8^{\mathrm{a}}$ & $>99$ & $>200$ \\
\hline A. niger/yam II starch & $2^{c}$ & $>99$ & $>200$ & $15^{\mathrm{b}}$ & $>99$ & $>200$ \\
\hline A. niger/yam I starch & $8^{\mathrm{a}}$ & $>99$ & $>200$ & $15^{\mathrm{a}}$ & $>99$ & $>200$ \\
\hline A. niger/yam I starch & $30^{c}$ & 76 & 10 & $25^{\mathrm{b}}$ & $>99$ & $>200$ \\
\hline A. niger/gelatin & $21^{\mathrm{a}}$ & 84 & 14 & $46^{\mathrm{a}}$ & 77 & 15 \\
\hline
\end{tabular}

Reaction conditions: $(R S)$-sec-butylamine (1) $(0.2 \mathrm{~mL}, 2 \mathrm{mmol})$, ethyl acetate $(0.2 \mathrm{~mL}, 2 \mathrm{mmol}), n$-hexane $(10 \mathrm{~mL}$ or $7 \mathrm{~mL}), A$. niger lipase/support $(50 \mathrm{mg}), 35^{\circ} \mathrm{C},{ }^{\mathrm{a}} 3 \mathrm{~min},{ }^{\mathrm{b}} 5 \mathrm{~min}$ and ${ }^{\mathrm{c}} 30 \mathrm{~min}$.

the acylation of $(R S)-\mathbf{1}$ with ethyl acetate under $\mathrm{CH}$ or MW irradiation. The results are presented in Table 3 .

Firstly, the reactions were carried out for $3 \mathrm{~min}$, considering that in a shorter reaction time no product was detected applying $\mathrm{CH}$. The results were also dependent on the support used. When A. niger lipase was used in the free form, applying $\mathrm{CH}$ or MW irradiation, the $(R)$-amide 2 was formed with conversion degrees of 13 and $45 \%$ and $e e_{\mathrm{p}}$ and E-values of 90 and $81 \%$ and 21 and 18, respectively. Under MW irradiation, an increase in the conversion degree was observed, but both the $e e_{\mathrm{p}}$ and E-values decreased in comparison with $\mathrm{CH}$.

In the case of A. niger lipase immobilized in the yam II starch film, on applying $\mathrm{CH}$ no product was formed. However, under MW irradiation the $(R)$-amide 2 was formed with a low conversion degree of $8 \%$, but with high $e e_{\mathrm{p}}$ and E-values, these being $>99 \%$ and $>200$, respectively.

When the A. niger lipase was immobilized in the yam I starch film, on applying $\mathrm{CH}$ or MW irradiation the $(R)$-amide 2 was obtained with conversions degrees of 8 and $15 \%$, resulting in $e e_{\mathrm{p}}$ and E-values of $>99 \%$ and $>200$, respectively. These results showed that on using MW irradiation, the conversion degree to $(R)$-amide $\mathbf{2}$ was around two times higher than that obtained using $\mathrm{CH}$.

The best results for the conversion degrees (21 and 46\%) were achieved when the A. niger lipase was immobilized in gelatin film and either $\mathrm{CH}$ or MW irradiation was applied. However, the $e e_{\mathrm{p}}$ and E-values were moderate (84 and $77 \%$ and 14 and 15, respectively). These data cannot be considered as appropriate for enzymatic resolution. ${ }^{3}$

As discussed above, the best results in relation to the enantioselectivity of the process were obtained using the $A$. niger lipase immobilized in yam I starch or yam II starch films and applying $\mathrm{CH}$ or MW irradiation, the positive effect of protecting the biocatalyst also being observed.

In order to increase the conversion degrees, the acylation of $(R S)-\mathbf{1}$ was achieved using the A. niger lipase/yam II starch and A. niger lipase/yam I starch systems and applying in longer reaction times.

When the acylation of $(R S)$-1 was carried out for $30 \mathrm{~min}$ under $\mathrm{CH}$ and using the $A$. niger lipase immobilized in yam II or yam I starch films, the $(R)$-amide 2 was obtained in conversion degrees of 2 and 30\%, respectively. The $e e_{\mathrm{p}}$ and $\mathrm{E}$-values were of 81 and $83 \%$ and $>200$ and 10, respectively. As observed, the conversion degree increased and the enantioselectivity of the process was dependent on the support (data presented on Table 3).

When the reaction was performed under MW irradiation for $5 \mathrm{~min}$, using the A. niger lipase immobilized in yam II or yam I starch films, the $(R)$-amide $\mathbf{2}$ was obtained in conversion degrees of 15 and $25 \%$. Interestingly, the $e e_{\mathrm{p}}$ and E-values were $>99 \%$ and $>200$, respectively. These data show an increase in the conversion degrees in comparison with those obtained in $3 \mathrm{~min}$ of reaction.

The A. niger lipase immobilized in yam II or yam I starch films was reused in the acylation of $(R S)$-1 1 for 5 min under MW irradiation, a sharp decrease in the E-values were observed, being about $85 \%$.

In summary, moderate conversion degrees and good enantioselectivity were obtained using A. niger lipase, free or immobilized in starch films, and applying conventional heating or MW irradiation. However, in general, the conversion degrees were higher using MW irradiation.

\section{Conclusions}

In this study, the resolution of (RS)-sec-butylamine (1) with various acyl donors was investigated using free or immobilized lipases, particularly A. niger lipase. The reactions were carried out using conventional heating and microwave (MW) irradiation, under different experimental conditions.

When the free A. niger lipase was used applying MW irradiation the degree of conversion to $(R)$-amide 2 was three times higher than that obtained under conventional 
heating using ethyl acetate as the donor acyl in $n$-hexane at $35^{\circ} \mathrm{C}$. Using the A. niger lipase/yam I starch and A. niger lipase/yam II starch systems and applying MW irradiation the $(R)$-amide 2 was obtained with conversion degrees lower than those using the free lipase. However, the selectivity was much better $\left(e e_{\mathrm{p}}>99 \%\right.$ and $\left.\mathrm{E}>200\right)$. Furthermore, using these systems the conversions, in general, were higher under MW irradiation (8-25\%) in relation to conventional heating $(0-30 \%)$.

In conclusion, the results obtained in this study showed that the use of immobilized lipases in combination with MW irradiation offers interesting advantages in relation to biocatalytic reactions, especially in the resolution of $(R S)-\mathbf{1}$.

\section{Acknowledgments}

This work was supported by the Universidade Federal de Santa Catarina (UFSC-Brazil), Coordenação de Aperfeiçoamento de Pessoal de Nível Superior (CAPES), Conselho Nacional de Desenvolvimento Científico e Tecnológico (CNPq) and INCT-Catalysis, which provided financial support and scholarships (M. G. N and C. P.). We also thank Amano Pharmaceutical Co. (Japan), Novozymes (Brazil) for the donation of lipases, and Prof. Marcus C. M. Sá (UFSC-Brazil) for the use of the microwave reactor.

\section{References}

1. Ghanem, A.; Tetrahedron 2007, 63, 1721.

2. Mitchell, D. A.; Moure, V. R.; Marques, F. A.; Krieger, N.; J. Mol. Catal. B: Enzym. 2010, 64, 23.

3. Faber, K.; Biotransformations in Organic Chemistry, $4^{\text {th }}$ ed., Springer-Verlag: New York, 2000, ch. 1-2, pp. 1-116.

4. Chen, H. M.; Wang, P. Y.; Tsai, S. W.; J. Taiwan Inst. Chem. Eng. 2009, 40, 549.

5. Contesini, F. J.; Lopes, D. B.; Macedo, G. A.; Nascimento, M. G.; Carvalho, P. O.; J. Mol. Catal B: Enzym. 2010, 67, 163.

6. Sun, J. H.; Daí, R. J.; Meng, W. W.; Deng, Y. L.; Catal. Commun. 2010, 11, 987.

7. Prasad, A. K.; Husain, M.; Singh, B. K.; Gupta, R. K.; Manchanda, V. K.; Olsen, C. E.; Parmar, V. S.; Tetrahedron Lett. 2005, 46, 4511.

8. Andrade, L. H.; Barcellos, T.; Santiago, C. G.; Tetrahedron: Asymmetry 2010, 21, 2419.

9. Evic, A. K.; Landek, G.; Dokli, I.; Vinkovic, V.; Tetrahedron: Asymmetry 2011, 22, 936.

10. Shaabani, A.; Soleimani, E.; Rezayan, A. H.; Tetrahedron Lett. 2007, 48, 6137.

11. Benz, G. In Comprehensive Organic Synthesis; Trost, B. M.; Fleming, I., eds.; Pergamon: Oxford, 1991, vol. 6, pp. 381-418.
12. Bachu, P.; Gibson, J. S.; Sperry, J.; Brimble, M. A.; Tetrahedron: Asymmetry 2007, 18, 1618.

13. Fang, Y.; Huang, W.; Xia, Y. M.; Process Biochem. 2008, 43, 306.

14. Rufino, A. R.; Biaggio, F. C.; Santos, J. C.; De Castro, H. F.; Int. J. Biol. Macromol. 2010, 47, 5.

15. Kappe, C. O.; Angew. Chem., Int. Ed. 2004, 43, 6250.

16. Gelens, E.; Smeets, L.; Sliedregt, L. A. J. M.; Steen, B. J.; Kruse, C. G.; Leurs, R.; Orru, R. V. A.; Tetrahedron Lett. 2005, 46, 3751.

17. de Souza, R. O. M. A.; Antunes, O. A. C.; Kroutil, W.; Kappe, C. O.; J. Org. Chem. 2009, 74, 6157.

18. Yu, D.; Wang, Z.; Chen, P.; Jin, L.; Cheng, Y.; Zhoub, J.; Cao, S.; J. Mol. Catal. B: Enzym. 2007, 48, 51.

19. Ribeiro, S. S.; de Oliveira, J. R.; Porto, A. L. M.; J. Braz. Chem. Soc. 2012, 23, 1395.

20. Huang, W.; Xia, Y. M.; Gao, H.; Fang, Y. J.; Wang, Y.; Fang, Y.; J. Mol. Catal. B: Enzym. 2005, 35, 113.

21. Mateo, C.; Palomo, J. M.; Fernandez-Lorente, G.; Guisan, J. M.; Fernandez-Lafuente, R.; Enzyme Microb. Technol. 2007, 40, 1451.

22. Wang, A.; Liu, M.; Wang, H.; Zhou, C.; Du, Z.; Zhu, S.; Shen, S.; Ouyang, P.; J. Biosci. Bioeng. 2008, 106, 286.

23. Yilmaz, E.; Can, K.; Sezgin, M.; Yilmaz, M.; Biores. Technol. 2011, 102, 499.

24. Xie, W.; Ma, N.; Biomass Bioenerg. 2010, 34, 890.

25. Song, X.; Qi, X.; Qu, Y.; Colloids Surf., B 2008, 67, 127.

26. Rebelo, L. P.; Netto, C. G. C. M.; Toma, H. E.; Andrade, L. H.; J. Braz. Chem. Soc. 2010, 21, 1537.

27. Hoffmann, I.; Silva, V. D.; Nascimento, M. G.; J. Braz. Chem. Soc. 2011, 22, 1559.

28. Yadav, G. D.; Lathi, P. S.; J. Mol. Catal. A: Chem. 2004, 223, 51.

29. Contesini, F. J.; Carvalho, P. O.; Tetrahedron: Asymmetry 2006, 17, 2069.

30. Carvalho, P. O.; Calafatti, S. A.; Marassi, M.; Silva, D.; Contesini, F. J.; Bizaco, R.; Quím. Nova 2005, 28, 614.

31. Zaks, A.; Klibanov, A. M.; J. Biol. Chem. 1988, 263, 8017.

32. Dalla-Vecchia, R.; Sebrão, D.; Nascimento, M. G.; Soldi, V.; Process Biochem. 2005, 40, 2677.

33. Thomson, C. A.; Delaquis, P. J.; Mazza, G.; Crit. Rev. Food Sci. Nutr. 1999, 39, 165.

34. Acros Organics; Catalog of Organics and Fine Chemicals, 2006-2007, p. 74.

35. Singh, K.; Singh, K.; Tetrahedron 2009, 65, 10395.

36. Chen, C. S.; Fujimoto, Y.; Girdaukas, G.; Sih, C. J.; J. Am. Chem. Soc. 1982, 104, 7294.

37. Sih, C. J.; Wu, S. H.; Top. Stereochem. 1989, 19, 63.

38. Kazlauskas, R. J.; Weissfloch, A. N. E.; J. Mol. Catal. B: Enzym. 1997, 3, 65.

39. Pilissão, C.; Carvalho, P. O.; Nascimento, M. G.; J. Braz. Chem. Soc. 2010, 21, 973. 
40. Wen, S.; Tan, T.; Yu, M.; Process Biochem. 2008, 43, 1259.

41. Yadav, G. D.; Borkar, I. V.; Ind. Eng. Chem. Res. 2009, 48, 7915.

42. Laane, C.; Boeren, S.; Vos, K.; Veeger, C.; Biotechnol. Bioeng. 1987, 30, 81 .

43. Klibanov, A.; J. Biol. Chem. 2001, 409, 241.
44. Yu, D.; Ma, D.; Wang, Z.; Wang, Y.; Pan,Y.; Fang, X.; Process Biochem. 2012, 47, 479.

Submitted: May 29, 2012

Published online: September 4, 2012

FAPESP has sponsored the publication of this article. 